\title{
Local Content Policy, Human Capital Development and Sustainable Business Performance in the Nigerian Oil and Gas Industry
}

\author{
James Unam Monday ${ }^{1}$ \\ ${ }^{1}$ Department of Management and Accounting, Obafemi Awolowo University, Ile-Ife, Nigeria \\ Correspondence: James Unam Monday, Department of Management and Accounting, Obafemi Awolowo \\ University, Ile-Ife, Nigeria. E-mail: jumonday@oauife.edu.ng
}

Received: October 20, 2014

Accepted: November 27, 2014 Online Published: February 20, 2015

doi:10.5539/jms.v5n1p75

URL: http://dx.doi.org/10.5539/jms.v5n1p75

\begin{abstract}
This study examined the extent to which the Local Content Policy has impacted on human capital development and sustainable business performance in the Nigerian Oil and GasIndustry, following the enactment of enabling legislation. Primary data were employed, which were obtained through the administration of structured questionnaire to purposively selected oil servicing companies in Niger Delta, the home to more than eighty percent of the indigenous oil companies in Nigeria. The results showed that Local Content Policy had significant impact on the development of human capital in the Oil and Gas Industry. There was a paradigm shift in the educational capacity of the Management of the oil servicing firms as over $70 \%$ of them had at least first degree or its equivalent. Through oil sector linkages, the firms had strengthened their absorptive capacities to internalize the technological and managerial skills that flow to them. This had consequently boosted the business performance of indigenous oil servicing firmsin terms of growth in profit, market share and returned on investment (ROI). The study concluded that the Local Content Policy had achieved significant success in enhancing the development of human capital which in turn positively influenced business performance of indigenous companies in the Oil and Gas Industry in Nigeria.
\end{abstract}

Keywords: local content policy, human capital, sustainable business performance, oil and gas industry

\section{Introduction}

With increasingly globalisation, human capital as a necessity for industrial productivity has continually attracted both academic and public interests. Human capital is widely acknowledged as an agent of national development. Providing education or training to people is one of the major ways of improving the quality of human resources as no nation can survive with unseasoned workforce. Human capital development is crucial as humans are the ultimate capital that propels productivity. Humans beings are the most important and promising source of growth in productivity. Equipment and technology are products of human minds and can only be made productive by humans. The success of any productive program and project depends on human innovative ideas and creativity.

Human capital refers to the education, skill levels, and problem-solving abilities that will enable an individual to be productive. Human capital, in general, and education, in particular, helps people to perceive, evaluate and implement new production techniques and inputs (Cosar, 2011). Thus, human capital development refers to the process of acquiring and increasing the number of persons who have the education, skills, and problem-solving abilities which are critical for industries' performance and the economic growth of the country. In Nigeria, this can be achieved through the increase in Local Content which is the value added or created in the Nigerian economy through the utilization of Nigerian human and material resources for the provision of goods and services.

As developing countries like Nigeria seek to improve their industrial base through the development of human capital, Local Content Policy has been widely viewed as a central part of this effort. Since 1956 when oil was discovered in commercial quantity in Nigeria, human capital development in the Petroleum Industry had been relatively low. The Nigerian Government invest enormously into its Oil and Gas Industry, but only very little portion of the profits from the investments is spent in developing her industrial base as the lion shares were paid to foreign firms for services such as Fabrication, Engineering Procurement Construction (EPC), Front End Engineering Design (FEED), conceptual designs and seismic studies. This often resulted in capital flight as the 
profits from the oil business were repatriated abroad; thus, providing employment opportunities for citizens of other countries, and in most cases developed countries (Ihua, 2010, Monday, 2012).

In recognition of the anomaly in the Nigerian Oil and Gas Industry, the Federal Government introduced the Local Content (LC) Policy in the year 2000, and precisely a decade after, signed the enabling legislation. The essence was to increase the local content and consequently boost human capital development and competitive capabilities of indigenous firms in the Oil and Gas Industry. The level of human capital is a key factor in explaining the level of technology diffusion from multinational companies to their host countries and it provides a competitive advantage $(\mathrm{Xu}, 2000)$. Therefore, the main aim of this study was to examine the progress of the local content policy and how it has impacted on human capital development and business performance in the Nigerian Oil and Gas Industry.

\section{Literature Review}

At the discovery of oil in Nigeria in 1956, the country was not yet independent and almost the whole venture into the oil and gas business was carried out by foreigners. Thetechnology, equipment, personnel and risk was their own both in exploration, exploitation, processing and management of product. All efforts in the industry were owned by foreigners and the country only owned the resources (Ozigbo, 2008). Thus, Nigeria depended on royalties from the operators. Under this arrangement, only the Nigerian government earned money directly from the oil and gas business. At that time, the educational and technological advancement of the country had not reached the stage which they could participate in the industry.

Over time as the country's socio-economic status grew, joint venture agreements were drawn between Nigeria and the participating oil companies in the industry aimed at partnering all aspects of the trade with Nigerians with the view to transferring technology as work progresses. The Nigerian Petroleum Industry has come of age yet foreign participation was still found to dominate the scene in all aspects including carriage of crude oil. Scholars and industry experts confirmed low local content as the major cause of the situation. This drove the Nigerian Government to initiate the Local Content Policy in the year 2000 (Ihua, 2010). The government pushing for increased local content in the Petroleum Industry gave a legislative backing in early 2010 through the enactment of the Local Content Act (Ozim, 2010; Monday, 2012).

Local Content (LC) in the Petroleum Industry has been defined as a set of deliberate orientation and actions to build domestic capacity and sustainable culture of service quality and capabilities exceeding customers' expectations and comparable to international standards through key indigenous personnel and management (Obuaya, 2005). A more comprehensive definition was offered by the NNPC (2006), as "The quantum of composite value added or created in the Nigerian economy through the utilization of Nigerian human and material resources for the provision of goods and services to the Petroleum Industry within acceptable quality, health, safety and environment standards in order to stimulate the development of indigenous capabilities". It can also be defined as the integrated contributions to myriad of operations or inputs in the crude oil and natural gas extraction process, which are made by Nigerian personnel, local contractors, wholly owned Nigerian companies or by Nigerian registered companies in which Nigerians effectively own a majority of the equity (Nwosu et al., 2006). Thus, Local Content Policy generally seeks to promote a framework which ensures that local competencies are built (to internationally acceptable standards) through the active participation of Nigerians, and the deployment of local resources and raw materials, in oil and gas related activities.

Local Content helps to drive employment, develop local skills, transfer technology, promote R\&D performance, and create wealth in the petroleumindustry. This is however subject to demonstration of capacity in equipment, personnel and other aspects of handling the contract. Where these criteria are met, such a Nigerian company shall be given preference over a non-Nigerian company. A Nigerian company is any company withownership and/or infrastructure in Nigeria that allows it to conduct manufacturing and service production in the country; that is, a company with staff who are Nigerians (Heum et al., 2003). In a nutshell, the essence of Local Content Act is to give Nigerian oil companies first consideration in the award of contracts and employment, and to contribute significantly to human capital development in the Petroleum Industry.

The term "human capital" has been defined as the stock of accumulated skills and experiences that make workers more productive (Stiglitz \& Boadway, 1994). Organisation for Economic Co-operation and Development (OECD) in 2001 defined human capital as "the knowledge, skills, competencies, and attributes embodied in individuals that facilitate the creation of personal, social and economic well-being". A more comprehensive definition of human capital was given by Marimuthu et al. (2009) as the processes that relate to training, education and other professional initiatives in order to increase the levels of knowledge, skills, abilities, values, and social assets of an employee which will lead to the employee's satisfaction and performance, and eventually 
on business performance. Therefore, human capital is a key element in improving a firm (likewise industry) assets and employees in order to increase productivity and sustain competitiveness.

Human capital development is about supporting cum investing in human capital, coaching, training, internship and human capital management (Enyekit et al., 2011). It presupposes investments, activities and processes that produce vocational and technical education knowledge, skills, health and values that are embodied in people. It implies building an appropriate balance and critical mass of human resource base and providing an enabling environment for all individuals to be fully engaged and contribute to goals of an organization, industry or a nation. Any effort to increase human knowledge, enhance skills, productivity and stimulate resourcefulness of individuals is an effort of human capital development (Erluwua, 2007). Human capital development refers to the process of acquiring and increasing the number of persons who have the skills, education and experience which are critical for industries' performance and the economic growth of the country.

The significance of developing human capital in any industry cannot be over-emphasized. In the assessment of 192 countries, human capital on the average accounted for $64 \%$ of the total wealth while physical and natural capital accounted for $16 \%$ and $29 \%$ respectively (World Bank, 1998). Thus, investment in human capital is an objective of development; it is a way to fulfil the potential of people by enlarging their capabilities. This implies empowerment of people which enable them to participate actively in their own development.

Human capital development is a source of innovation and improvement toward achieving organizations' goals. Human capital in the form of skilled labour isa major determinant of productivity level (Benhabib \& Spiegel, 2002). In the same vein, Cosar (2011) revealed that technology diffusion does not only take place through formal $\mathrm{R} \& \mathrm{D}$, but through the employment of skilled labour in general. Therefore, human capital facilitates technology adoption.Adequate investment in human capital serves as catalyst for improved industrial productivity.Substantial studies were carried out on human capital and their implications on firm's performance on widely basis and the results showed that human capital enhancement results in greater firm's competitiveness and industrial performance (Barney, 1995; Simon-Oke, 2012)

UNCTAD/CALAG (2006) pointed out that increasing local content could have positive effect on human capital in form training and education, which is an instrument to increase productivity and sustain competitiveness in the organization and industry. Human capital development tend to create a significant contribution on organizational competencies which in turn becomes a great boost for further enhancing innovativeness.Literature to a large extent supports the fact that business performance is positively impacted by the presence of human capital practices (Noe et al., 2003; Youndt et al., 2004; Marimuthu et al., 2009); and some even endorsed that human capital development is a prerequisite to sustainable business performance (Delaney \& Huselid, 1996).

The development of human capital is positively influenced by the educational level of employees and their overall satisfaction. Therefore, development human capital has a direct impact on return on investment (ROI) of firms. Similar studies (Shrader \& Siegel, 2007; Monday et al., 2012) have shown that the relevance of human capital to business performance has also become prevalent among the technology-based new ventures, and it seems that the use of human capital tool (emphasizing quality of employees) in small technology-based new ventures tends to have a great impact on the firms' success.

From the foregoing, a simple conceptual model is developed to show the relationship between local content policy, human capital and business performance.

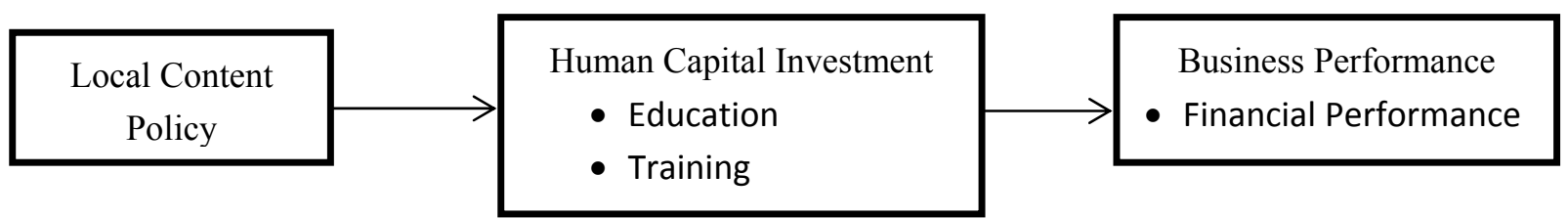

Figure 1. Conceptual model linking local content policy, human capital, and business performance

Based on the literature reviews, it is therefore postulated that local content policy stimulates investment in human capital which consequently leads to greater business performance. Business performance can be viewed as the financial performance. In the Petroleum Industry, financial performance includes return on investment (ROI), market share and growth in profit. 
Local Content which is well known for its value addition to the industrial base of an economy has drawn the attention of many policy-makers and researchers, both in developed and developing nations. Several authors have conducted researches on how Local Content Policy has impacted onhuman capital development andcorporate performancein the Nigerian oil and gas industry. Recent studies by Ozigbo (2008) addressed the impact of local content policy on local capacity building in the Nigerian Oil and Gas Industry. He found that the local content in the industry was still very low as over 60 percent of the work value in the oil and gas sector was carried out abroad. This, he said, has led to dearth in skills development, capacity building/utilisation and poor business performance. The study concluded that partnering or alliance formation of various forms (especially with the multi-nationals) is an important tool in the development of the Oil and Gas Industry, especially where the required capital and indigenous technical capacity are relatively in short supply.

Ihua (2010) examined the relationship between local content policy and the business performance in the Oil and Gas Industry. He revealed that the local content policy has not yet achieved significant success in enhancing higher indigenous participation, use of local technology, higher contract awards to indigenous firms and stimulating joint venture arrangements between indigenous and foreign oil firms. This studyfurther identified the hindrances to the policy efficacy to include lack ofthe Local Content Act, cumbersome prequalification and entry requirements, underfunded and ill-equipped educational institutions, laissez-faire attitude of multinationals, ineffective monitoring and control by regulatory authorities, and inadequate financing options for indigenous SMEs.

In the most recent study by Oyejide and Adewuyi (2011) on the implications of Local Content Policy and the extent of the linkages that the oil sector has created with the rest of the Nigerian economy, found that the linkage between the oil servicing firms and the oil majors as well as with the local research centres or universities to be weak, although Local Content Policy has made some significant impacts in the oil sector in terms of contract awards.

Vaaland et al. (2012) investigated how local content can be enhanced in the oil and gas industry in a developing country like Nigeria. The empirical base was in-depth interviews of professionals directly orindirectly related to the Nigerian oil and gas industry. The interviews revealed barriers for indigenouscompanies in accessing the industry. These were related to three major capabilities; capital, competence and delivery possibilities. It is suggested that the barriers can be solved by recognition ofthe interdependencies between actors associated with these capabilities. The actors include in additionto the foreign companies and the indigenous companies, educational institutions, legal system, educational and $\mathrm{R}$ and $\mathrm{D}$ institutions, financial institutions, industrial regulators and providers of infrastructure.

\section{Methodology}

The research was conducted in the Niger Delta since more than eighty percent of the indigenous oil companies in Nigeria have their operational bases located in the area (PETAN, 2010). The study employed primary and secondary sources of data. Primary source of data was structured questionnaire which was administered to respondents in the indigenous oil companies, while the secondary sources included firms' annual reports, and publications of the Petroleum Technology Association of Nigeria (PETAN) which provided the list of registered indigenous oilfield service companies in the oil and gas industry.

Previously tested questionnaire used in African Oil and Gas Services Sector Survey by United Nations Conference on Trade and Development (UNCTAD) in collaboration with CALAG Capital (2006), and some list of variables used by Oyejide and Adewuyi (2011) in their study of"Enhancing Linkages of Oil and Gas Industry in the Nigerian Economy"were consulted in designing the questionnaire for this study. The study was carried out in 2012.

According to PETAN (2010), the population of localoilcompanies operating in the Niger Delta was thirty-eight (38). This represented the sample size for this study as the method of investigation was the census survey which provided an opportunity of describing the prevalent situation in the Nigerian oil and gas industry. Purposive sampling technique was employed to gather data from the heads of administration, human resources as well as those of operations/engineering and technical services in each of the companies.

According to Arundel (2005), stakeholders in the European policy community preferred detailed descriptive analysis for policy-related studies, particularly when combined with case studies. Since this study is policy-related and with a case study of indigenous oil companies in the Niger Delta, the method of data analysis was predominantly descriptive. 


\section{Results and Discussion}

Out of the 38 copies of the questionnaire administered, 24 were thoroughly filled and returned giving a high response rate of 63\%. Research (Cohen \& Arieli, 2011; Haer \& Becher, 2012) acknowledges the difficult nature of obtaining data in conflict regions like the Niger Delta. The analysis of this study was based on the retrieved copies of the questionnaire.

Local Content development is an initiative on the part of the Nigerian Government to enhance the performance of oil servicing companies. This can be achieved through the development of educational and professional competence of indigenous personnel, and effective oil sector linkages. This subsection investigates the extent that the Local Content Policy has affected the human capital development and business performance of local firms following the enactment of the Nigerian Oil and Gas Industry Content Act 2010.

\subsection{Impact of Local Content Policy on Human Capital Development in the Oiland Gas Industry}

Human capital development begins with development of management capabilities to increase the pool of skilled personnel for institutional networking. Vaaland et al. (2012) expressed that there is a significant knowledge gap between indigenous oil companies and foreign oil companies, especially in the area of management competence such as project management and quality assurance. Their study revealed that indigenous oil companies suffered from fundamental lack of quality management, limited compliance with international quality standards, and poor preventive and operational maintenance attitudes, which lead to poor maintenance of oil facilities. Local Content Policy, therefore, makes it pertinent for local entrepreneurs to upgrade their academic qualifications and professional experience which consequently boost their management capabilities to compete favourably in the industry.

Heum et al. (2003) and Ihua (2010) articulated that the Nigerian petroleum industry lacks adequate locally trained experts and skilled manpower. The analysis in Table 1 showed that there is a paradigm shift in the educational capacity of the management of the indigenous oil companies. Today the industry has an appreciable pool of locally trained experts and skilled manpower as almost all the major oil business owners $(70.8 \%)$ possess university degrees. About $29 \%$ classified as 'Others' constitutes holders of National Diploma (ND), vocational certificate and high school certificate with training abroad in oil and gas operations or worked in oil and gas companies abroad. In terms of professional experience, about $17 \%$ of the owners studied petroleum related courses abroad, $63 \%$ of the owners attended oil \& gas training abroad, while $42 \%$ worked in oil companies abroad.

Table 1. Management capabilities of the owners of indigenous oil and gas companies

\begin{tabular}{lll}
\hline Position & Academic Qualification & Percentage \\
\hline M.D/C.E.O & Postgraduate Degree & 25.0 \\
& Bachelor Degree or its equivalent & 45.8 \\
& Others & 29.1 \\
\cline { 2 - 3 } & Professional Experience & 16.7 \\
\cline { 2 - 3 } & Study Petroleum related Courses abroad & 62.5 \\
& Attend oil \& gas training abroad & 41.7 \\
\hline
\end{tabular}

Table 2 showed a five-year human resource profile of the selected indigenous oil companies. Based on the findings by the studies of Oladele (2001), Heum et al. (2003), Neff (2005), Ihua (2010), and Monday et al. (2012), the Nigerian oil and gas industry was dominated by foreign workers who created more jobs for their brothers in the oil service sector because local oil companies were alleged to comprise of less skilled employees. With the presence of the Local Content Policy, there has been an increase in the human resource profile of indigenous oil companies. According to the information supplied by the companies, the total skilled workforce was 1,283 in 2006 and in 2010; it has risen to 2,735 Nigerians which is approximately $47 \%$ increase.Besides, many of the employees were experienced in the oil business as they had spent considerable number of years in the industry. Although theincrease appears not too significant, it gives us the hope that the Local Content Policy is positively contributing to human capital development in the Nigerian oil and gas industry. Therefore, the policy has also promoted local participation in the industry. 
Table 2. A 5-year human resource profile of indigenous oil and gas companies

\begin{tabular}{llllll}
\hline Education & 2006 & 2007 & 2008 & 2009 & 2010 \\
\hline Postgraduate Degree & 8 & 11 & 12 & 18 & 32 \\
$\quad$ Bachelor Degree \& HND & 280 & 342 & 437 & 802 & 1062 \\
$\quad$ Others & 995 & 1224 & 1408 & 1315 & 1641 \\
$\quad$ Total & 1283 & 1577 & 1857 & 2135 & 2735 \\
\hline Years of Experience & & & & & \\
\hline 1 & 106 & 298 & 283 & 282 & 635 \\
2 & 148 & 104 & 298 & 282 & 266 \\
3 & 164 & 148 & 104 & 298 & 273 \\
4 & 167 & 164 & 145 & 104 & 298 \\
5 & 236 & 165 & 164 & 142 & 98 \\
More than 5 & 462 & 698 & 863 & 1027 & 1165 \\
Total & 1283 & 1577 & 1857 & 2135 & 2735 \\
\hline
\end{tabular}

\subsection{Local Content Policy and Linkages in the Nigerian Oil and Gas Industry}

Creating linkages between the oil and gas sector and other sectors of the Nigerian economy has been found to be a concrete solution to the problem of low technological capacity and poor business performance (Oyejide \& Adewuyi, 2011; Vaaland et al., 2012). Oyejide and Adewuyi further stressed that the overall objective of the policy is to promote local value addition, build local capacity and improved linkage between the oil and gas industry and other sectors of the Nigerian economy. Local content policy is therefore a critical means of creating and/or promoting linkages in the oil and gas industry.

This study showed the various ways of creating linkages in the oil industry which include encouraging research and development in domestic firms, encouraging partnership between firms, universities and research institutes involved in $\mathrm{R} \& \mathrm{D}$, organising and supporting training programmes, providing access to financial and non-financial business services and consultancy. The experiences of the domestic oil servicing firms with their collaboration and alliance partners were encouraging (see Table 3).

The study showed that all the indigenous oil companies were involved in some form of linkages with indigenous companies or institutions as well as foreign companies outside the borders of Nigeria. From the analysis in Table 3 , the mean score of collaborations with other indigenous oil companies was 2.83 out of a possible maximum score of 3.00, suggesting an effective (94.3\%) networking among indigenous oil companies. This is possible due to the clustering of the oil companies at Trans Amadi Industrial Layout in Port Harcourt and Airport Road in Warri.

Contrary to previous findings obtained before the enabling legislation on Local Content Policy was signed, there is appreciable linkage between the indigenous oil companies and the multinational oil companies.This was attested to by a mean score of 2.19 out of a possible maximum score of 3.00 , depicting an appreciable (73.0\%) collaboration. The local oil companies now partner with foreign companies to execute contracts; which if done with technically competent foreign companies could result in technical expertise, transfer of knowledge and technology.

The linkage between the domestic oil companies and the Higher Education Institutions (HEIs) which comprise universities and polytechnics, ranked the least with a mean score of 1.91 . This is an indication of a fair (63.7\%) collaborationdue to the weak standard of the Nigerian educational system. The academic institutions should be a focal point for research and production of skilled manpower and trained experts. As emphasized by Ihua (2010), "oil and gas business is a high risk business, requiring skilled technical manpower and that, only an effective educational system that understands the human resource needs of the industry and tries to match their resources to meeting those needs, can enhance the prospects of higher local content; without which the whole idea of local content would be a mirage, only ending as prospects". The interfaces between the graduate students, researchers and local oil business community are weak, resulting in weak exchange of knowledge and feedback loops (Vaaland et al., 2012).

Also, linkage between the local oil companies and Research institutes (RIs) recorded a mean score of 2.17, depicting an appreciable (72.3\%) level of collaboration. These oil servicing firms collaborated with the universities, polytechnics and research institutes in the areas of training, research and consultancy. Building inter-organizational relationships between the oil companies and HEIs/RIs promotes exchange of research, educational, managerial and technological skills which consequently enhance competitiveness of both parties. 
Interestingly, the domestic oil companies engaged in collaboration activities more with training institutes such as the Petroleum Training Institute (PTI), Nigerian Institute of Welders (NIW), technical colleges, etc. This was attested to by a mean value of 2.53 , indicating a high level $(84.3 \%)$ of collaboration.

In the areas of funding and infrastructural supports, the linkages between the indigenous oil servicing firms and Nigerian financial institutions (Commercial, Bank of Industry, and Microfinance Banks) as well as Government Ministries/Agencies have been encouraging to some extent. The mean scores of 2.64 for financial institutions and 2.67 for Government Ministriesrevealed high level (88\% and $89 \%$ respectively) collaborations. The local oil companies collaborated with local financial institutions for funding, and training in financial proficiency, and with Government Ministries/Agencies such as the Ministry of Energy and Petroleum Resources, Niger-Delta Development Commission (NDDC), and Petroleum Trust Development Fund (PTDF).

Table 3. Effect of local content policy on oil sector linkages

\begin{tabular}{lc}
\hline Collaboration partner & Mean \\
\hline Indigenous oil-servicing firms & 2.83 \\
Multinational oil firms & 2.19 \\
Higher Education Institutions & 1.91 \\
Research Institutes & 2.17 \\
Training Institutions & 2.53 \\
Financial Institutions & 2.64 \\
Government Ministries/Agencies & 2.67 \\
\hline
\end{tabular}

\subsection{Impact of Local Content Policy on Business Performance of the Oil Companies}

Considering the performance of the local oil companies, Table 3 showed that the Local Content Policy has actually stimulated human capital development and linkages between the oil and gas sector and other sectors of the Nigerian economy, which have resulted in enhanced capabilities in winning contract awards and increased profitability of the indigenous oil companies.

The analysis in Table 4 showed the financial performance of the indigenous oil companies after the enactment of the Local Content Act.The mean score of growth in profit was 2.46 out of a possible maximum score of 3.00, depicting a significant $(82 \%)$ growth in the profit of indigenous oil companies. In the same vein, growth in market share had a mean score of 2.36, indicating a significant (78.67\%) growth in the firms' market shares. Also, the firms' return on investment (ROI) recorded a mean score of 2.01 while growth in ROI was 2.08, out of maximum score of 3.00. These results indicated an appreciable measure of return on investment of the indigenous oil companies. From the foregoing, it is obvious that local content policy has contributed in no small measure to business performance in the Nigerian oil and gas industry.

The increase in the business performance of the indigenous oil companies cannot be viewed as significant enough to help in curbing the unemployment in the country as it is expected that the oil and gas sector would help create enormous job opportunities, especially for youths from the oil producing Niger Delta region. Government needs to encourage the local production and fabrication of required materials and equipment in Nigeria. This can be done by enhancing a more friendly business environment such as the granting of special concessions, free land and tax breaks for companies who agree to come and set up production factories. The resultant effect of this is that, it would not only develop Nigeria's thin industrial base; but would also provide sustainable job opportunities for unemployed youths and prevent incidences of civil disturbancesand social vices (Ihua, 2010).

Table 4. Impact of local content policy on business performance of oil companies

\begin{tabular}{lc}
\hline FinancialPerformance & Mean \\
\hline Growth in profit & 2.46 \\
Growth in market share & 2.36 \\
Return on investment (ROI) & 2.01 \\
Growth in ROI & 2.08 \\
\hline
\end{tabular}




\section{Conclusion and Recommendation}

The ultimate goal of the Local Content Policy is to promote the business performance of indigenous oil companies through effective human capital development and linkages with the oil sector as well as the rest of the Nigerian economy. Based on the survey data, Local Content Policy has made significant contributions to the development of human capital and business performance of the Nigerian oiland gas industry as all of the companies were involved in some form of linkages which have strengthened their absorptive capacity to internalize the technological and management skills that flow to them. However, the linkages between the indigenousoil companies and the universities/polytechnics were rather weak. This can lead to poor performance of research and development (R\&D) and inability to develop and use local technology in the industry.

This study therefore recommends that Government should fully fund and equip theNigerian tertiary institutions and public research institutes, so they can engage in efficient linkages with indigenous oil companies. Besides, local oil companies should endeavour to sponsor more training and educational activities of their workers as well as upgrading their technology in order to meet the required standard of the oil industry.

\section{References}

Arundel, A. (2005). Innovation Surveys and Policy: Lessons from the CIS. Technology Policy Briefs, 4(1), 8-10.

Barney, J. B. (1995). Looking Inside for Competitive Advantage. Academy of Management Executive, 9(4), 49-61.

Benhabib, J., \& Spiegel, M. M. (2002). Human Capital and Technology Diffusion. FRBSF Working Paper \#2003-02, 1-48.

Cohen, N., \& Arieli, T. (2011). Field Research in Conflict Environments: Methodological Challenges and Snowball Sampling. Journal of Peace Research, 48(4), 423-435. http://dx.doi.org/10.1177/0022343311405698

Cosar, A. K. (2011). Human Capital, Technology Adoption and Development. The B. E. Journal of Macroeconomics, 11(1), 1-41. http://dx.doi.org/10.2202/1935-1690.1907

Delaney, J. T., \& Huselid, M. A. (1996). The Impact of Human Resource Management Practices on Perceptions of Organizational Performance. Academy of Management Journal, 39(4), 949-969. http://dx.doi.org/10.2307/256718

Enyekit, E. O., Amaehule, S., \& Teerah, L. E. (2011). Achieving Human Capital Development In Nigeria Through Vocational Education For Nation Building. Proceedings of the 2011 International Conference on Teaching, Learning and Change (pp. 63-69). International Association for Teaching and Learning (IATEL).

Erluwua, H. E. O. (2007). Skills Acquisition: A Tool for Youth Empowerment for Economic Growth and Development. Journal of Business and Management Studies, 1(2), 116-125.

Haer, R., \& Becher, I. (2012). A Methodological Note on Quantitative Field Research in Conflict Zones: Get your Hands Dirty. International Journal of Social Research Methodology, 15(1), 1-13. http://dx.doi.org/10.1080/13645579.2011.597654

Heum, P., Quale, C., Karlsen, J. E., Kragha, M., \& Osahon, G. (2003). Enhancement of Local Content in the Upstream Oil and Gas Industry in Nigeria: A Comprehensive and Viable Policy Approach. Bergen, Norway: SNF Report No. 25/03.

Ihua, U. B. (2010). Local Content Policy and SMEs Sector Promotion: The Nigerian Oil Industry Experience. Int'l Journal of Business and Management, 5(5), 3-13. http://dx.doi.org/10.5539/ijbm.v5n5p3

Marimuthu, M., Arokiasamy, L., \& Ismail, M. (2009). Human Capital Development and Its Impact on Firm Performance: Evidence from Developmental Economics. The Journal of International Social Research, 2(8), 265-272.

Monday, J. U. (2012). Local Content Policy and Performance of Small to Medium-scale Oil Servicing Enterprises in Nigeria. Unpublished M. Phil. thesis in Business Administration. Ile-Ife, Nigeria: Obafemi Awolowo University.

Monday, J. U., Agorzie, C. J., \& Asaolu, T. O. (2012). Local Content Policy and Technological Capacity Building of SMEs in the Nigerian Oil and Gas Industry. Proceedings of the 5th Nigerian Association for Energy Economics (NAEE) Conference, Abuja, 23-24 April, 352-368. 
Neff, S. (2005). Memorandum on International Best Practice in Development of Local Content in the Energy Sector. Paper presented to Nigeria National Stakeholders Working Group, Goldwyn International Strategies, LLC, 4th May.

NNPC (2006). Nigerian Content. Retrieved from www.nnpconline.org

Noe, R. A., Hollenbeck, J. R., Gerhart, B., \& Wright, P. M. (2003). Human Resource Management: Gaining a Competitive Advantage (4th ed.). Boston: McGraw-Hill.

Nwosu, H. U., Nwachukwu, I. N., Ogaji, S. T., \& Probert, S. D. (2006). Local Harnessing in Crude Oil and $\begin{array}{lllll}\text { Natural Gas in Nigeria. Applied } & \text { Energy, }\end{array}$ http://dx.doi.org/10.1016/j.apenergy.2005.09.001

Obuaya, T. (2005). Local Content Implementation in Nigeria: A Road Map. Paper presented at the Nigerian Oil and Gas Conference, Abuja, Nigeria, 18-20 April.

Oladele, A. O. (2001). Opportunities for Indigenous Participation in Upstream Industries. Paper presented at the NNPC Workshop on Improvement of Local Content, Warri, Delta, 4-20.

Oyejide, T. A., \& Adewuyi, A. O. (2011). Enhancing Linkages of Oil and Gas Industry in the Nigerian Economy. MMCP Discussion Paper No. 8, University of Cape Town and Open University.

Ozigbo, N. C. (2008). Technological Capacity Building in the Nigeria's Oil and Gas Industry. Proceedings of the 19th Annual International Information Management Association, San Diego, CA, 13-15 October, 51-63.

Ozim, I. O. (2010). Analysis of the Nigerian Oil and Gas Industry Content Act 2010. Aelex Newsletter, Lagos, $1-6$.

PETAN Brochure. (2010). "Members Profile”, Petroleum Technology Association of Nigeria, Abuja, Nigeria.

Simon-Oke, O. O. (2012). Human Capital Investment and Industrial Productivity in Nigeria.International Journal of Humanities and Social Science, 2(16), 298-307.

Stiglitz, J. E., \& Boadway, R. W. (1994). Economics and the Canadian Economy. New York: W.W. Norton \& Company.

United Nations Conference on Trade and Development (UNCTAD)/CALAG Capital. (2006). Creating Local Linkages by Empowering Indigenous Entrepreneurs (Volume 1 - Nigeria). New York and Geneva: African Oil and Gas Services Sector Survey by United Nations.

Vaaland, T. I., Soneye, A. S., \& Owusu, R. A. (2012). Local Content and Struggling Suppliers: A Network Analysis of Nigerian Oil and Gas Industry. African Journal of Business Management, 6(15), 5399-5413. http://dx.doi.org/10.5897/AJBM11.2538

World Bank. (1998). Knowledge for Development. World Development Report 1998/99, Washington, D.C.

Xu, B. (2000). Multinational Enterprises, Technology Diffusion, and Host Country Productivity Growth. Journal of Development Economics, 62(2), 477-493. http://dx.doi.org/10.1016/S0304-3878(00)00093-6

Youndt, M. A., Subramaniam, M., \& Snell, S. A. (2004). Intellectual Capital Profiles: An Examination of Investments and Returns. Journal of Management Studies, 41(2), 335-361. http://dx.doi.org/10.1111/j.1467-6486.2004.00435.x

\section{Copyrights}

Copyright for this article is retained by the author(s), with first publication rights granted to the journal.

This is an open-access article distributed under the terms and conditions of the Creative Commons Attribution license (http://creativecommons.org/licenses/by/3.0/). 